\title{
Provenance, Tectonics and Paleoclimate of Permo-Carboniferous Talchir Formation in Son-Mahanadi Basin, Central India with Special Reference to Chirimiri: Using Petrographical Interpretation
}

\author{
Khansa Zaidi $^{1 *}$, Sarwar Rais ${ }^{1}$, Abdullah Khan ${ }^{1}$, Mohd Masroor Alam ${ }^{2}$ \\ ${ }^{1}$ Department of Geology, Aligarh Muslim University, Aligarh, India \\ ${ }^{2}$ Department of Civil Engineering, Aligarh Muslim University, Aligarh, India \\ Email: *khansa.scholar@gmail.com, raissarwar56@gmail.com
}

Received October 28, 2013; revised November 29, 2013; accepted December 24, 2013

Copyright (C) 2014 Khansa Zaidi et al. This is an open access article distributed under the Creative Commons Attribution License, which permits unrestricted use, distribution, and reproduction in any medium, provided the original work is properly cited. In accordance of the Creative Commons Attribution License all Copyrights (c) 2014 are reserved for SCIRP and the owner of the intellectual property Khansa Zaidi et al. All Copyright (C) 2014 are guarded by law and by SCIRP as a guardian.

\begin{abstract}
The present study deals with the petrographic interpretation of Talchir Formation sandstone, in and around Chirimiri area, Koriya district, Chhattisgarh state India located in Son-Mahanadi basin. This basin is an elongate graben showing northwest-southeast trend and considered to be one of the largest intra-cratonic rift basins of Indian peninsula. Talchir Formation is the lowermost unit of thick classical Gondwana sedimentary succession and rests unconformably on Precambrian basement. The petrographic studies consisting of point count show the presence of quartz as a dominant framework mineral with subordinate amounts of feldspars and rock fragments. The data plot in the fields of cratonic interior and transitional margin of continental block provenance. In the Qt (quartz)-F (feldspar)-L (lithic fragments) triangular diagram, indicating the source of these sediments was located in transitional margin and continental block provenance. The petrographic classification suggests that this formation in the study area dominantly contains compositionally immature to submature arkosic, sub-arkosic and lithic-arkosic sandstones. The bivariate plot between $Q p /(F+R)$ vs. $Q t /(F+R)$ indicates changes in climatic conditions from semi-arid to semi-humid during Permo-Carboniferous period.
\end{abstract}

\section{KEYWORDS}

Son-Mahanadi; Talchir Formation; Chirimiri; Provenance; Tectonics; Petrography; Paleoclimate

\section{Introduction}

The compositions of sandstone have been widely used by sedimentologists during past several decades to decipher the provenance, paleoclimate and tectonic setting of the source areas [1-9]. The characters of detrital framework grains are substantially affected by the nature of processes that act in the depositional basin and also by the type of transporting medium and distance of transport $[8,10]$. Determination of different aspects of provenance viz its location with respect to depositional basin, lithology, climate and tectonic setting is some of the important parameters of basin analysis [11].

\footnotetext{
"Corresponding author.
}

The Gondwana sediments of Peninsular India mark the resumption of sedimentation during Permo-Carboniferous after a long hiatus since Proterozoic. The sedimentation in Gondwana basins of India evolved through a complex interplay of faulting, changes in sea level and climate [12]. The basinal geometry was modified by tectonic movement during different periods. Indian plate is an assembly of several micro continents, sutured along early/middle Proterozoic Mobile belts [13-15]. These mobile belts became the locales of rift nucleation and played a fundamental role in the mechanism of rift propagation along reactivated ancient shear zones [15-18]. These intra-cratonic rifts are referred to as Gondwana basins. 
The Gondwana basins are linearly arranged along the present day river valleys viz. Koel-Damodar, SonMahanadi and Pranhita-Godavari (Figure 1(b)). The sediments are mostly made up of clastics of glacial and glacigene rocks at the base followed by coal measures and red beds at the top [19]. The Talchir Formation, the lowermost member of Gondwana sequence of India, is suggested to be of glacial, glacio-fluvial, glacio-lacustrine and/or glacio-marine depositional environment [20-32]. The Talchir Formation is marked by uniformly deposited olive green sandstone, conglomerate, thinly laminated shales, siltstone, and varves with typical glacigene facies tillite mostly at the base.

The present study is based on modal analysis of

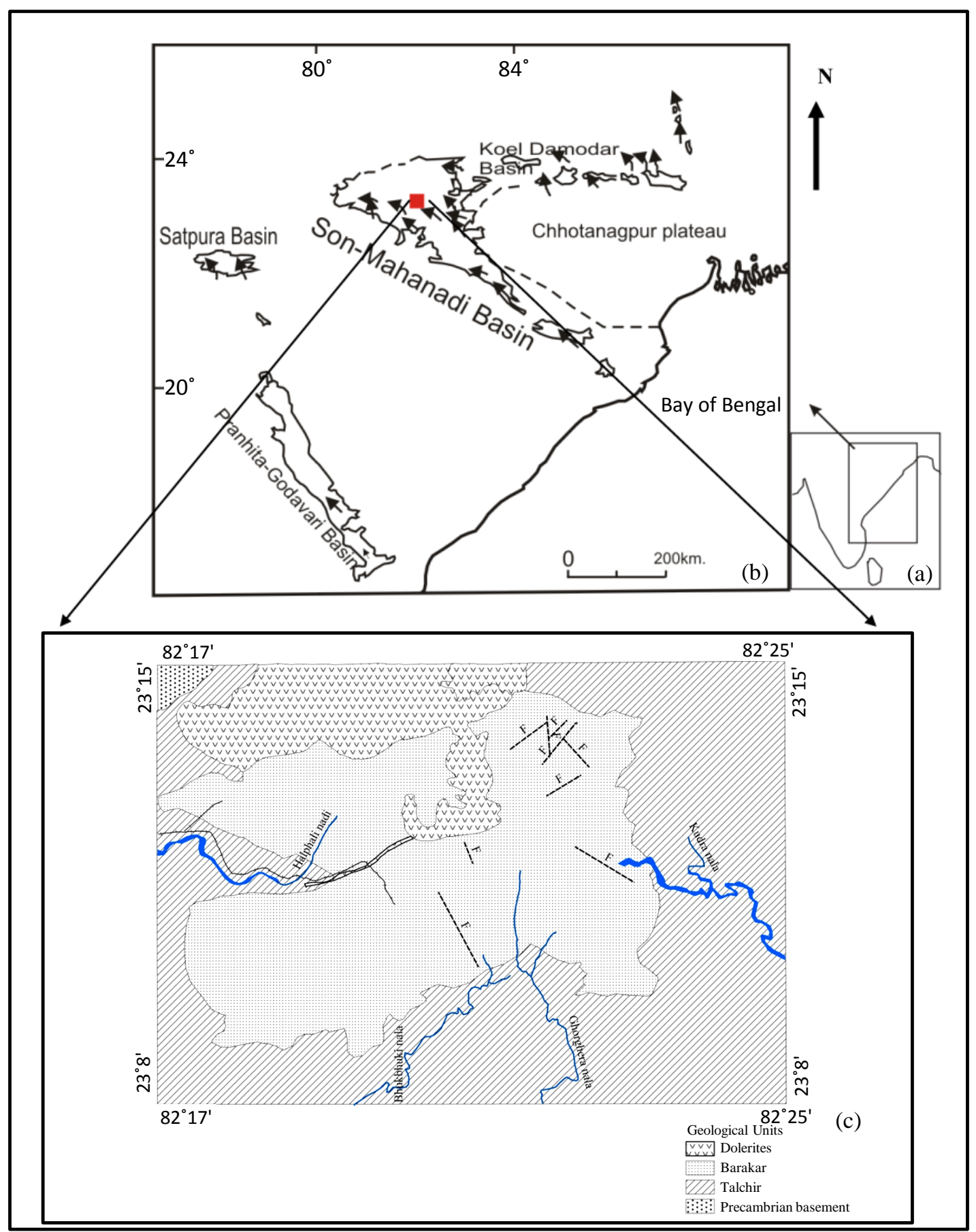

Figure 1. (a) Map of India shown inset; (b) The outline map of Peninsular India showing Gondwana basins and paleohighlands. Arrows indicate direction of Permian-Triassic paleoslope modified by Tewari and Veevers, 1993; (c) Map showing study area modified after Raja Rao 1983. 
sandstones of Talchir Formation of Chirimiri, Koriya district, Chhattisgarh state, located in Son-Mahanadi basin (Figure 1(c)). The aim of the study is to interpret the possible provenance, tectonic setting and paleoclimate variability that led to the deposition of these sandstones during Permo-Carboniferous period.

\section{Geological Setting}

The Chirimiri coalfield, the study area, is a part of SonMahanadi basin falls between latitudes $23^{\circ} 8^{\prime} \mathrm{N}$ to $23^{\circ} 15^{\prime} \mathrm{N}$ and longitudes $82^{\circ} 17^{\prime} \mathrm{E}$ to $82^{\circ} 25^{\prime} \mathrm{E}$. Talchir Formation is exposed along streams flowing in the vicinity of Chirimiri town. Olive green, thinly laminated shales and medium grained sandstone succeeded by lemon yellow alternate beds of shale and sandstones are found exposed in this area. The Chirimiri area was surveyed by C.S Raja Rao and stratigraphic succession was proposed (Table 1) [33].

The Son-Mahanadi graben is one of the largest intracratonic rift basins of peninsular India. The Mahakoshal supracrustal lie in the north of Son-Mahanadi Gondwana basin. The rocks of Sausar mobile belt and Betul supracrustals are exposed in the south, whereas the eastern and south eastern fringes of the Son-Mahanadi basin are constituted by granite-gneissic complex of Chotanagpur terrain and Precambrian rocks of Singhbhum and Bastar craton respectively [34]. To the west of the basin unclassified Precambrian migmatites and geneisses are exposed. Tectonically, the basin has been divided into three blocks i.e., Son, Hasdo-Arand and Mahanadi separated from each other by ENE-WSW trending prominent basement ridge [35]. Spatial distribution of rock units, variation in the thickness of sediments, different disposition of structural elements and contrasting lineament-trends of these three blocks suggest that each underwent a different sedimentation and tectonic history [35].

\section{Material and Methods}

The current study deals with petrographic interpretations of Talchir sandstones in Chirimiri area. 50 Talchir sandstone samples have been collected along the stream cuttings in and around Chirimiri, where they are found exposed. The streams from where these samples have been collected are Halphali, Kudra, Bhukbhuki, and Ghorghera (Figure 1(c)). Out of these 50, only 29 representative samples of sandstone were selected for petrographic studies. Thin sections of the selected samples were prepared by standard technique. Modal analysis of samples was carried out using point counting method to determine the quantitative mineralogical aspects of these sandstones. About 350 points per thin section were counted (Table 2) using Gazzi-Dickenson's method [36]. The counted grains were recalculated into percentage as summarised in (Table 3).
Table 1. Stratigraphic succession of Chirimiri, coalfield Koriya district, Chhattisgarh (Raja Rao, 1983).

\begin{tabular}{|c|c|c|}
\hline Age & Formation & Lithology \\
\hline $\begin{array}{l}\text { Upper Cretaceous } \\
\text { to lower Eocene (?) }\end{array}$ & Deccan Traps & Basic flows, dykes and sills. \\
\hline Lower Permian & Barakar & $\begin{array}{l}\text { Essentially sandstone with } \\
\text { subordinate Shales and coal } \\
\text { seams ( } 230 \mathrm{~m} \text { to } 435 \mathrm{~m}) .\end{array}$ \\
\hline \multirow[t]{2}{*}{$\begin{array}{c}\text { Upper } \\
\text { Carboniferous to } \\
\text { Early Permian }\end{array}$} & Talchir & $\begin{array}{l}\text { Predominantly olive green } \\
\text { shales and Medium to fine } \\
\text { grained sandstone. }\end{array}$ \\
\hline & UNCONFORMITY & \\
\hline $\begin{array}{c}\text { Precambrian } \\
\text { basement }\end{array}$ & & $\begin{array}{c}\text { Granite, Gniesses and } \\
\text { Quartzite }\end{array}$ \\
\hline
\end{tabular}

Table 2. Key for petrographic and other parameters used in this study (modified after Dickinson 1985).

\begin{tabular}{|c|c|}
\hline \multicolumn{2}{|r|}{ QFR } \\
\hline $\mathrm{Q}$ & Total Quartz grains (Qm + Qp) \\
\hline Qm & monocrystalline quartz \\
\hline Qp & polycrystalline quartz \\
\hline $\mathrm{F}$ & Total Feldspar (P + K) \\
\hline $\mathrm{P}$ & Plagioclase \\
\hline $\mathrm{K}$ & alkali feldspar \\
\hline $\mathrm{R}$ & Total rock fragments including chert \\
\hline \multicolumn{2}{|r|}{ QtFL } \\
\hline Qt & Total quartz grains (Qm + Qp) \\
\hline Qm & monocrystalline quartz \\
\hline Qp & polycrystalline quartz \\
\hline $\mathrm{F}$ & Total Feldspar (P + K) \\
\hline $\mathrm{P}$ & Plagioclase \\
\hline $\mathrm{K}$ & alkali feldspar \\
\hline $\mathrm{L}$ & Total lithic fragments \\
\hline \multicolumn{2}{|r|}{ QmFLt } \\
\hline Qm & monocrystalline quartz \\
\hline $\mathrm{F}$ & Total Feldspar (P + K) \\
\hline $\mathrm{P}$ & Plagioclase \\
\hline $\mathrm{K}$ & alkali feldspar \\
\hline Lt & Total rock fragments including polycrystalline quartz \\
\hline \multicolumn{2}{|r|}{ QpLvLs } \\
\hline Qp & polycrystalline quartz \\
\hline $\mathrm{Lv}$ & Total volcanic and Meta-volcanic rock fragments \\
\hline Ls & Total sedimentary rock fragments \\
\hline \multicolumn{2}{|r|}{ LmLvLs } \\
\hline $\mathrm{Lm}$ & Total metamorphic rock fragments \\
\hline $\mathrm{Lv}$ & Total volcanic rock fragments \\
\hline Ls & Total sedimentary rock fragments \\
\hline \multicolumn{2}{|r|}{$\mathrm{Qp} / \mathrm{F}+\mathrm{RF}$ vs. Qt/F + RF } \\
\hline Qt & Total quartz grains (Qm + Qp) \\
\hline Qm & monocrystalline quartz \\
\hline Qp & polycrystalline quartz \\
\hline $\mathrm{F}$ & Total Feldspar (P + K) \\
\hline $\mathrm{RF}$ & Total rock fragments \\
\hline
\end{tabular}


Table 3. Recalculated detrital composition of Talchir sandstones of Chirimiri area, Koriya district.

\begin{tabular}{|c|c|c|c|c|c|c|c|c|c|c|c|c|c|c|c|c|c|}
\hline \multirow{2}{*}{ S.No } & \multicolumn{3}{|c|}{ QFR } & \multicolumn{3}{|c|}{ QtFL } & \multicolumn{3}{|c|}{ QmFLt } & \multicolumn{3}{|c|}{ QpLvLs } & \multirow{2}{*}{$\mathbf{Q p} /(\mathbf{F}+\mathbf{R})$} & \multirow{2}{*}{$\mathbf{Q t} /(\mathbf{F}+\mathbf{R})$} & \multicolumn{3}{|c|}{ QmPK } \\
\hline & $\mathbf{Q}$ & $\mathbf{F}$ & $\mathbf{R}$ & Qt & $\mathbf{F}$ & $\mathbf{L}$ & Qm & $\mathbf{F}$ & Lt & Qp & $\mathbf{L v}$ & Ls & & & Qm & $\mathbf{P}$ & K \\
\hline NT1 & 71.23 & 16.44 & 12.33 & 60.46 & 38.37 & 1.17 & 71.23 & 16.44 & 12.33 & 0 & 0 & 100 & 0.11 & 1.52 & 60.47 & 0 & 39.55 \\
\hline NT2 & 70.42 & 15.49 & 14.08 & 57.89 & 40.35 & 1.76 & 70.42 & 15.49 & 14.08 & 0 & 0 & 100 & 0.21 & 1.37 & 56.90 & 0 & 43.1 \\
\hline NT3 & 69.62 & 18.99 & 11.39 & 52.40 & 43.26 & 4.34 & 69.62 & 18.99 & 11.39 & 0 & 0 & 100 & 0.25 & 1.1 & 55 & 15 & 30 \\
\hline NT5 & 61.54 & 19.23 & 19.23 & 55.26 & 39.48 & 5.26 & 61.54 & 19.23 & 19.23 & 0 & 0 & 100 & 0.21 & 1.23 & 58.33 & 5.55 & 36.12 \\
\hline NT7 & 67.57 & 18.92 & 13.51 & 54.17 & 29.17 & 16.7 & 67.57 & 18.92 & 13.51 & 0 & 0 & 100 & 0.13 & 1.18 & 65 & 0 & 35 \\
\hline NT8 & 91.67 & 4.86 & 3.47 & 68.94 & 28.43 & 2.63 & 91.67 & 4.86 & 3.47 & 66.66 & 0 & 33.34 & 0.03 & 1.38 & 70.49 & 4.26 & 25.25 \\
\hline NT9 & 80.13 & 16.03 & 3.85 & 68.57 & 24.58 & 6.85 & 80.13 & 16.03 & 3.85 & 0 & 0 & 100 & 0.17 & 1.55 & 73.61 & 2.47 & 23.92 \\
\hline NT10 & 73.53 & 13.24 & 13.24 & 76.36 & 23.64 & 0 & 73.53 & 13.24 & 13.24 & 0 & 0 & 0 & 0.12 & 1.55 & 76.36 & 1.81 & 21.83 \\
\hline NT12 & 71.11 & 22.22 & 6.67 & 58.1 & 37.4 & 4.5 & 71.11 & 22.22 & 6.67 & 0 & 0 & 0 & 0.06 & 1.56 & 60 & 7.5 & 32.5 \\
\hline NT13 & 70.71 & 20.20 & 9.09 & 83.54 & 16.46 & 0 & 70.71 & 20.20 & 9.09 & 0 & 0 & 0 & 0.11 & 1.56 & 85.71 & 1.3 & 12.99 \\
\hline NT14 & 71.43 & 23.81 & 4.76 & 62.92 & 35.96 & 1.12 & 71.43 & 23.81 & 4.76 & 33.33 & 0 & 66.67 & 0.26 & 1.64 & 63.64 & 0 & 36.36 \\
\hline GN1 & 73.36 & 18.22 & 8.41 & 77.38 & 17.86 & 4.76 & 54.55 & 27.27 & 18.18 & 70 & 0 & 30 & 0.28 & 2.05 & 66.66 & 4.44 & 28.9 \\
\hline GN2 & 64.10 & 25.00 & 10.90 & 72.12 & 21.15 & 6.73 & 67.31 & 21.15 & 11.54 & 45.5 & 0 & 54.5 & 0.16 & 1.54 & 76 & 3 & 21 \\
\hline GN3 & 67.57 & 21.62 & 10.81 & 69.70 & 24.24 & 6.06 & 69.70 & 24.24 & 6.06 & 0 & 0 & 100 & 0.23 & 1.68 & 74.2 & 3.22 & 22.58 \\
\hline GN4 & 61.74 & 26.85 & 11.41 & 61.90 & 29.25 & 8.84 & 60.54 & 29.25 & 10.20 & 13.33 & 0 & 86.67 & 0.03 & 1.62 & 67.42 & 3.02 & 29.56 \\
\hline GN5 & 84.52 & 11.90 & 3.57 & 77.65 & 20.00 & 2.35 & 77.65 & 20.00 & 2.35 & 0 & 0 & 100 & 0.2 & 0.91 & 79.53 & 8.43 & 12.04 \\
\hline GN6 & 74.65 & 14.08 & 11.27 & 74.20 & 17.35 & 8.45 & 67.74 & 17.74 & 14.52 & 33.33 & 0 & 66.67 & 0.17 & 2 & 79.24 & 0 & 20.76 \\
\hline GN7 & 76.11 & 19.44 & 4.44 & 68.75 & 27.60 & 3.65 & 62.50 & 27.60 & 9.90 & 66.67 & 16.7 & 16.67 & 0.21 & 1.05 & 69.38 & 9.82 & 20.8 \\
\hline GN8 & 79.40 & 16.08 & 4.52 & 78.61 & 18.41 & 2.99 & 64.68 & 18.41 & 16.92 & 80.02 & 11.4 & 8.57 & 0.7 & 1.95 & 77.84 & 1.2 & 20.96 \\
\hline GN9 & 79.14 & 10.07 & 10.79 & 63.16 & 29.47 & 7.37 & 56.00 & 32.00 & 12.00 & 44.44 & 0 & 55.56 & 0.16 & 1.69 & 65.85 & 3.04 & 31.11 \\
\hline GN10 & 71.64 & 22.39 & 5.97 & 70.78 & 26.23 & 2.99 & 68.81 & 26.24 & 4.95 & 40 & 10 & 50 & 0.06 & $1 . .46$ & 72.39 & 2.6 & 25.01 \\
\hline GN11 & 82.05 & 11.11 & 6.84 & 87.27 & 10.91 & 1.82 & 82.50 & 10.00 & 7.50 & 80 & 0 & 20 & 0.15 & 1.92 & 87.27 & 2 & 10.73 \\
\hline BBK1 & 71.43 & 14.29 & 14.29 & 49.25 & 42.25 & 8.50 & 45.54 & 43.56 & 10.90 & 0 & 14.29 & 85.71 & 0.11 & 0.83 & 51 & 0 & 49 \\
\hline BBK3 & 59.70 & 22.39 & 17.91 & 53.00 & 44.00 & 3.00 & 52.11 & 45.07 & 2.82 & 100 & 0 & 0 & 0.05 & 1.14 & 53.62 & 0 & 46.38 \\
\hline BBK4 & 63.37 & 28.71 & 7.92 & 70.00 & 24.00 & 6.00 & 53.33 & 26.67 & 20.00 & 100 & 0 & 0 & 0.05 & 1.43 & 42.3 & 3.84 & 53.86 \\
\hline BBK5 & 51.28 & 25.64 & 23.08 & 41.00 & 53.00 & 6.00 & 39.64 & 54.05 & 6.31 & 0 & 33.33 & 66.67 & 0.17 & 1.17 & 45.5 & 0 & 54.5 \\
\hline BBK6 & 73.96 & 20.71 & 5.33 & 38.89 & 55.56 & 5.56 & 38.89 & 55.56 & 5.55 & 100 & 0 & 0 & 0.35 & 0.63 & 63.69 & 10.71 & 25.6 \\
\hline BBK7 & 77.92 & 10.39 & 11.69 & 63.32 & 33.67 & 3.02 & 60.80 & 38.07 & 1.13 & 90 & 0 & 10 & 0.26 & 1.72 & 66.66 & 16.66 & 16.68 \\
\hline KN3 & 74.11 & 14.29 & 11.61 & 56.62 & 40.44 & 2.94 & 56.92 & 42.31 & 0.77 & 75 & 0 & 25 & 0.03 & 1.3 & 57.37 & 0 & 42.63 \\
\hline
\end{tabular}

\section{Petrography}

These sandstones are predominantly coarse to medium grained. Quartz is the chief component of these thin sections. It occurs in three varieties, monocrystalline, polycrystalline, and stretched (Plates 1(a) and (b)), the percentage of quartz ranges from 38.89 to 83.54 percent. The mono-crystalline quartz has both straight to slightly undulatory extinction with angular to subrounded grains. Detrital feldspar comes next to quartz, followed by rock fragments. Feldspar form 10.9 to 55.56 percent in these sandstones followed by rock fragments which range from
3.47 to 23.08 percent. Three varieties of feldspar, that is, orthoclase, plagioclase and microcline have been recorded in these sandstones (Plates 1(c)-(e)). Feldspar grains are fresh, coarse to medium in size and sub rounded in shape. Some feldspar grains also exhibits slight alteration (Plate 1(d)). Orthoclase is more abundant than rest of the feldspar varieties. Heavy minerals observed in these thin sections include zircon, rutile, garnet and epidote, along with rock fragments of granite/ gneiss, schist (Plate $1(\mathrm{~g})$ ), chert, shale and siltstone. Clay matrix is the common binding material present, along 


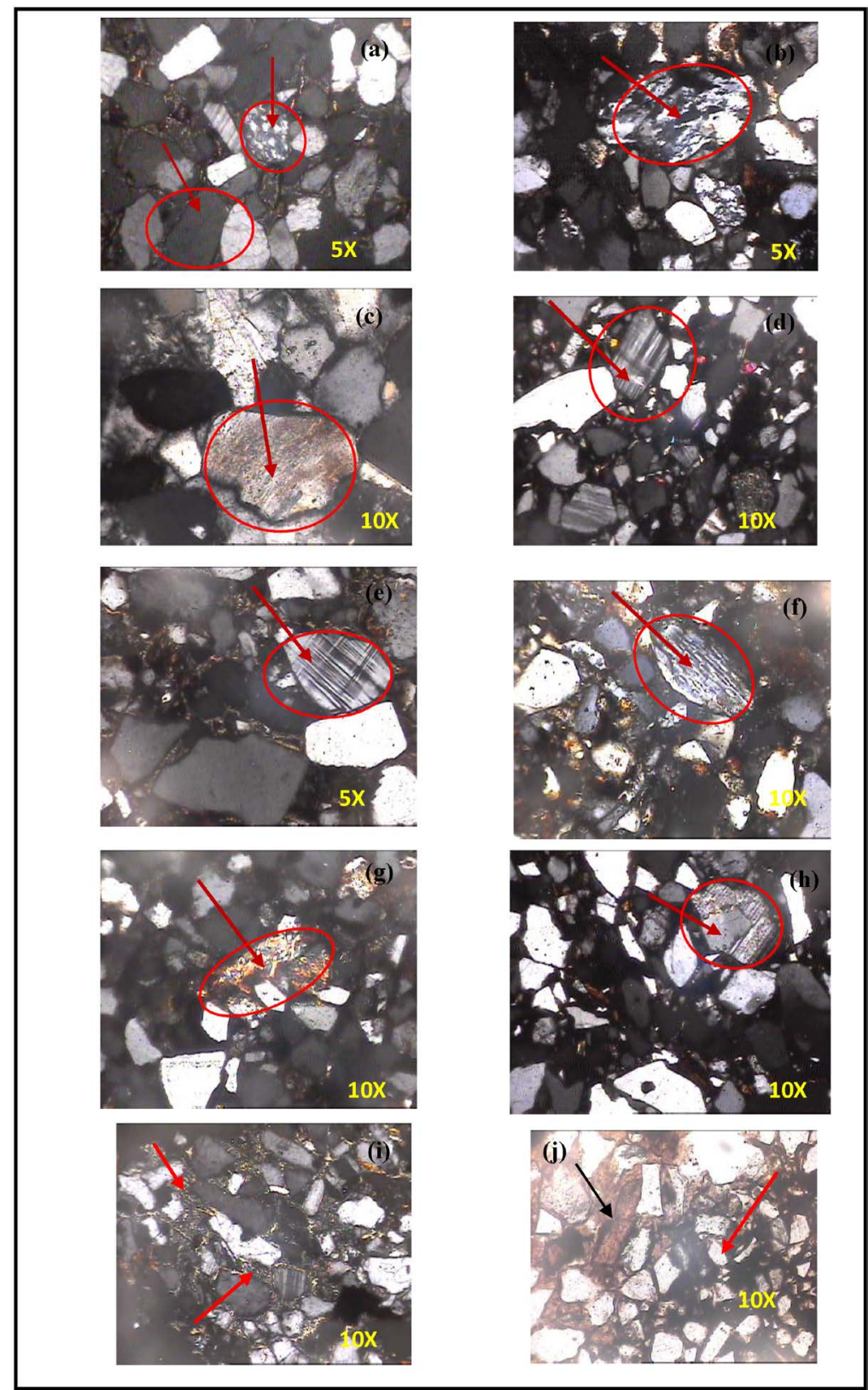

Plate 1. (a) Photomicrographs of Talchir Formation of Chirimiri area, Koriya district, Chhattisgarh, arrows showing monocrystalline quartz grains and polycrystalline quartz; (b) Stretched quartz; (c) Orthoclase grain showing iron staining; (d) Plagioclase grain slightly altered; (e) Microcline grain; (f) Perthite grain; (g) Schist fragment; (h) Plagioclase grain with inclusion of quartz; (i) Pore filling clay matrix; (j) Undifferentiated matrix (black in colour) and Iron cement (black arrow).

with ferruginous cement occurring at the edges of the grain or in small patches. Pore filling matrix is also common in these sandstones of Talchir Formation (Plate 1(i)) Undifferentiated matrix (Plate 1(j)) and few patches of calcite cement have also been encountered in framework of some of these studied samples.

The studied Talchir sandstone specimens of Chirimiri area have been classified according to Folk's classification [37] into three categories viz arkose, subarkose, and lithic arkose (Figure 2).

\section{Provenance, Tectonic Setting and Paleoclimate}

The studied sandstones of Talchir Formation, Chirimiri area have been plotted in QtFL diagram (Figure 3(a)), where most of the samples concentrate on continental block provenance and recycled orogen. QmFLt ternary plot also shows the same result (Figure 3(b)). The QmPK plot (Figure 4(a)) of the studied samples shows that these Talchir sandstones have been derived from continental block provenance. The QpLvLs (Figure 4(b)) 


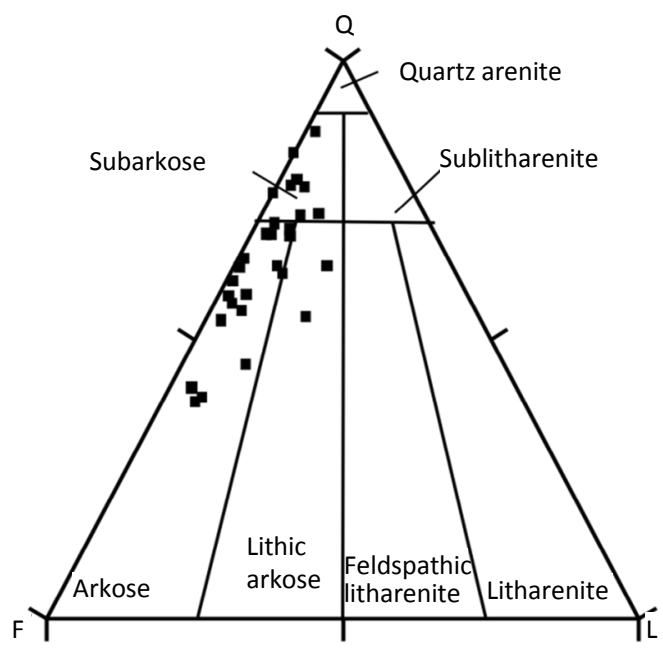

Figure 2. Classification of Talchir sandstone, Chirimiri area, Koriya district, Chhattisgarh (after Folk, 1980).

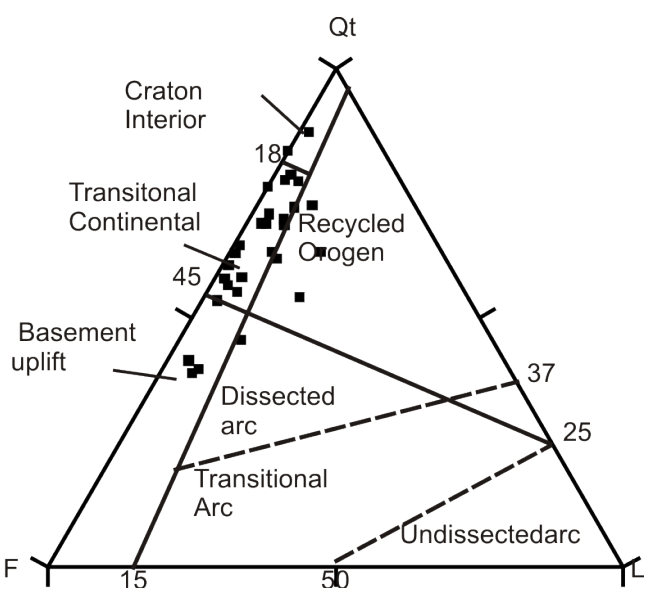

(a)

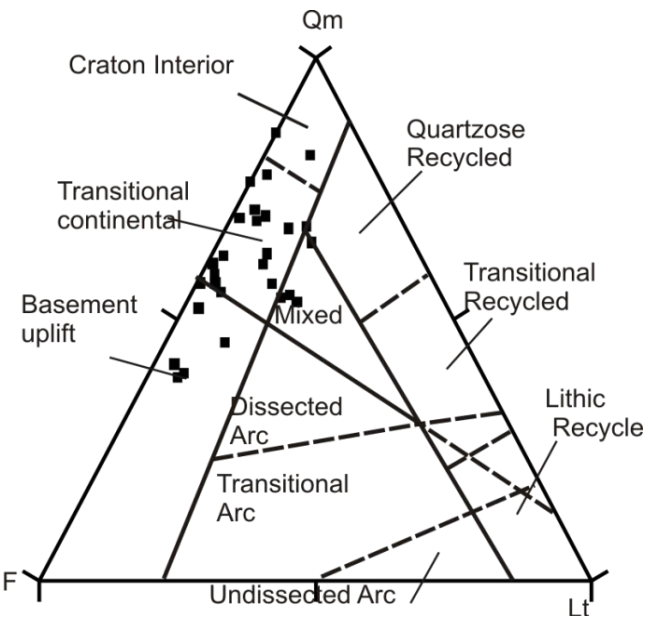

(b)

Figure 3. (a) Triangular diagram QtFL of Talchir sandstones, Chirimiri, Koriya for Provenance (after Dickinson et al., 1985). (b) Triangular diagram QmFLt of Talchir sandstones, Chirimiri. Koriya for Provenance (after Dickinson et al., 1985).

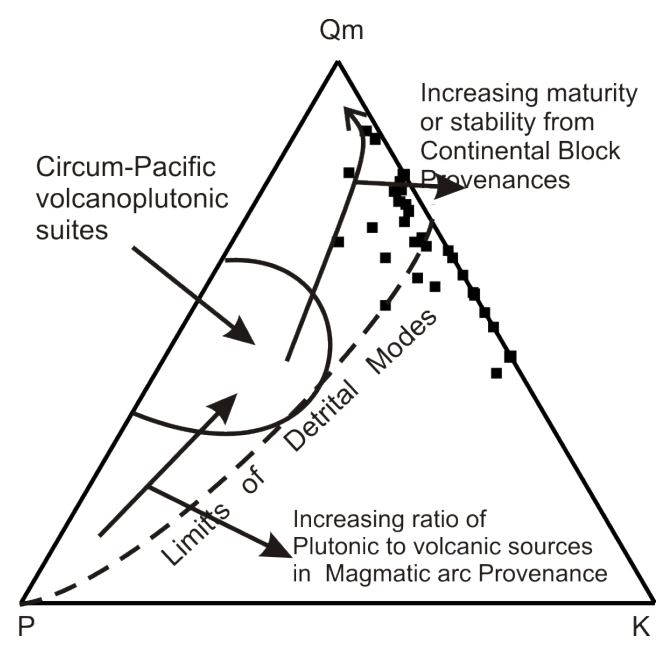

(a)

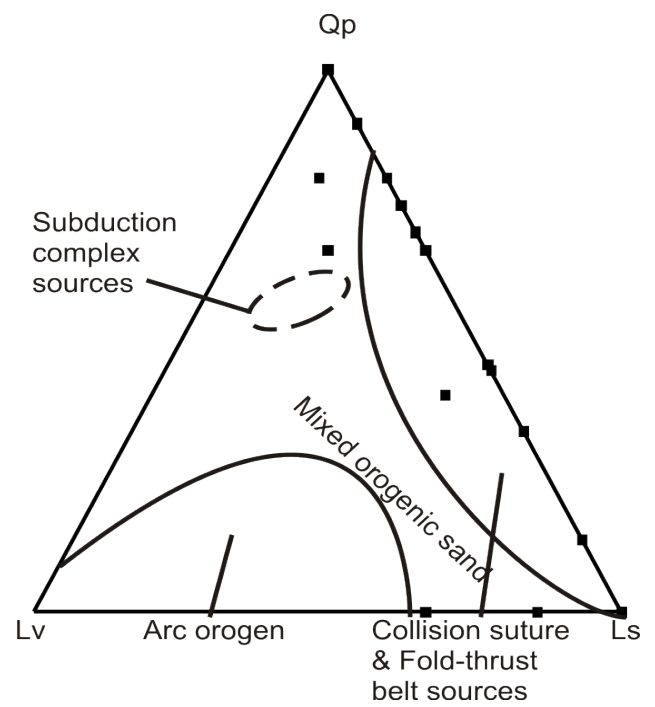

(b)

Figure 4. (a) Triangular diagram QmPK of Talchir sandstones, Chirimiri, Koriya district, for Provenance (after Dickinson et al., 1985). (b) Triangular diagram QpLvLs of Talchir sandstones, Chirimiri, Koriya district for Provenance (after Dickinson et al., 1985).

diagram based on lithic fragments population, suggests collision suture and fold thrust belt as source of these sandstones. The study of past climate of Permo-Carboniferous period is based on mineral composition of sandstone using bivariate plot between $\mathrm{Qt} /(\mathrm{F}+\mathrm{R}) \mathrm{vs}$. Qp/(F + $\mathrm{R}$ ) as shown in (Figure 5). The samples show variation in climate, changing gradually from semi-arid to semihumid.

\section{Results and Discussion}

The modal analysis of studied Talchir sandstones (Table 3 ), plotted on ternary diagram indicates that the sediments of Talchir Formation of Chirimiri, Koriya district, 


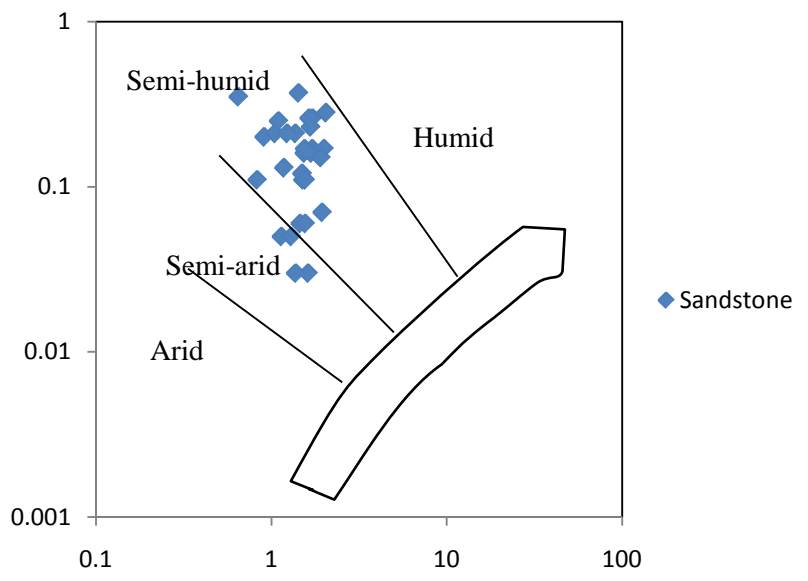

Figure 5. Bivariate log-log plot of $Q t /(F+R)$ and $Q p /(F+R)$ ratios of Talchir sandstones, Chirimiri, Koriya district, in climate discrimination diagram (after Suttner and Dutta, 1986).

Chhattisgarh were derived from continental block provenances and recycled orogen (Figure 3(a)). Within these major provenances sediments were derived from transitional continental block, basement uplift and small inputs also came from mixed field as shown in (Figure 3(b)). Continental block comprises variety of rocks, ranging from felsic-intermediate-mafic igneous, metamorphic and sedimentary to volcano-sedimentary assemblages. Recycled orogen sediments are sedimentary and subordinate volcanic rocks, which are metamorphosed and exposed to the surface by erosion and uplift of fold belts and thrusts. Some of these sediments were derived from recycled orogeny as shown in (Figure 4(b)). It can be interpreted from the present study that these sediments were derived from transitional continental region of continental block, which are generally of intermediate composition and provided compositionally immature to sub-mature sediments to the basin as shown in (Figure 4(a)). The palaeoflow data indicates that, in this part of peninsular India depositing streams were flowing from East-South- East to West-North-West during late Paleozoic [22]. On the basis of type of detrital framework components and available paleocurrent data it may be suggested that the provenance of the studied sandstone samples was probably Chotanagpur/Singhbhum craton and some other metasediments exposed in the vicinity of the basin. The studied samples show (Figure 5) that during late Palaeozoic era the climate changed gradually due to drifting of Indian sub continent towards the equator [8].

The quartz grains in shape ranges from angular to subrounded with strain lamellae in some of these grains. Angularity of some quartz grains indicate that these are first cycle of erosion sediments or have suffered some short distance of transportation whereas subrounded to rounded grains are either of second cycle or have been transported for longer distance. The preponderance of non-undulatory monocrystalline quartz over undulatory quartz suggests plutonic source. Automorphic inclusion of heavy mineral like zircon and tourmaline in monocrystalline quartz and grains of perthite (Plate $\mathbf{1}(\mathbf{f})$ ) are direct evidences of granitic source. Some mono crystalline quartz, are free from inclusions of heavy mineral and shows slight undulose extinction signifying that older gneiss or schist rocks might be the source [38]. The presence of iron oxide cement on feldspar grains also depict humid climate [10,39,40].

\section{Conclusions}

On the basis of the petrological data of the sandstone specimens of Talchir Formation (Permo-Carboniferous) collected from Chirimiri, Koriya district, Chhattisgarh, the following conclusions can be drawn:

1) These sandstones samples are compositionally immature to submature and have been classified as arkosic, subarkosic and lithic arkosic type.

2) Constituent grains of these sediments suggest their derivation continental block provenance.

3) Paleocurrent data indicate that the source area of these sandstones was somewhere in the East-South-East of the basin, which may be Chhotanagpur/Singhbhum complex with some contribution from Bastar craton also.

4) During the deposition of these Talchir sandstones, climate changed from semiarid to semi humid.

\section{Acknowledgements}

The authors are thankful to Dr. L.A.K Rao, Chairman and Dr. A.H.M. Ahmad, Incharge of sedimentology laboratory Department of Geology, A.M.U. Aligarh for providing the necessary facilities to carry out the research work. The financial assistance to Khansa Zaidi in the form of UGC (Maulana Azad National Senior Research Fellowship) is also gratefully acknowledged. The authors are also thankful to anonymous reviewer for suggesting necessary corrections in the manuscript.

\section{REFERENCES}

[1] F. J. Pettijohn, P. E. Potter, and R. Siever, "Sand and Sandstone,” Springer-Verlag, Berlin, 1972, p. 241.

[2] W. R. Dickinson and C. A. Suczek, "Plate Tectonics and Sandstone Compositions," American Association of Petroleum, Geological Bulletin, Vol. 63, No. 12, 1979, pp. 2164-2182.

[3] W. R. Dickinson, "Compositions of Sandstones in Circum-Pacific Subduction Complexes and Fore-Arc Basins,” American Association of Petroleum Geologists Bulletin Vol. 66, No. 2, 1982, pp. 121-137

[4] W. R. Dickinson, "Interpreting Provenance Relations from Detrital Modes of Sandstones,” In: G. G. Zuffa, Ed., 
Provenance of Arenites, D. Reidel Publ. Co., New York, 1985, pp. 333-361.

http://dx.doi.org/10.1007/978-94-017-2809-6_15

[5] W. R. Dickinson, "Provenance and Sediment Dispersal in Relation to Paleotectonics and Paleogeography of Sedimentary Basins,” In: K. L Kleinspehn and C. Paola, Eds., New Perspectives in Basin Analysis, Springer, New York, 1988, pp. 3-25. http://dx.doi.org/10.1007/978-1-4612-3788-4_1

[6] W. R. Dickinson, L. S. Beard, G. R. Brakenridge, J. R. Erjavee, R. C. Ferguson and K. F. Inman, "Provenance of North American Phanerozoic Sandstones in Relation to Plate Tectonic Setting,” Geological Society of American Bulletin, Vol. 94, No. 2, 1983, pp. 222-235. http://dx.doi.org/10.1130/0016-7606(1983)94<222:PON APS $>2.0 . C O ; 2$

[7] P. E. Potter, "South America and a Few Grains of Sand, Pt. I. Beach Sands,” Journal of Geology, Vol. 94, No. 3, 1986, pp. 301-319. http://dx.doi.org/10.1086/629031

[8] L. J. Suttner and P. K Dutta,., "Alluvial Sandstone Composition and Paleoclimate, I. Framework Mineralogy," Journal of Sedimentary Petrology, Vol. 56, No. 3, 1986, pp. 329-345.

[9] R. Cox and R. D. Lowe, "Quantifications of the Effects of Secondary Matrix on the Analysis of Sandstone Composition, and a Petro-Chemical Technique for Retrieving Original Framework Grain Modes of Altered Sandstones," Journal of Sedimentary Research, Vol. 66, No. 3, 1996, pp. 548-558.

[10] A. Basu, "Petrology of Holocene Fluvial sand Derived from Plutonic Source Rocks: Implications to Paleoclimatic Interpretation,” Journal of Sedimentary Petrology, Vol. 46, No. 3, 1976, pp. 696-709.

[11] Hota, et al., "Provenance Variability during Damuda Sedimentation in the Talchir Gondwana Basin, India-A Statistical Assessment," International. Journal of Geosciences, Vol. 2, No. 2, 2011, pp. 120-137.

[12] Mukhopadhyay, et al., "Stratigraphic Correlation between Different Gondwana Basins of India,” Journal of Geological Society of India, Vol. 76, No. 3, 2010, pp. 251266. http://dx.doi.org/10.1007/s12594-010-0097-6

[13] S. M. Naqvi and J. J. W. Rogers, "Precambrian Geology of India,” Clarendon Press, Oxford, 1987, p. 223.

[14] B. P. Radhakrishna and S. M. Naqvi, "Precambrian Continental Crust of India and Its Evolution,” Journal of Geology, Vol. 94, No. 2, 1986, pp. 145-166. http://dx.doi.org/10.1086/629020

[15] N. D. Mitra, “Tensile Resurgence along Fossil Sutures: A Hypothesis on the Evolution of Gondwana Basins of Peninsular India,” Abstracts of Proceedings 2nd Symposium on Petroliferous Basins of India, Vol. 3, Dehradun, 1994, pp. 55-62

[16] G. C. Chatterjee and P. K. Ghosh, "Tectonic Framework of Peninsular Gondwana of India,” Records Geological Survey of India, Vol. 98, No. 2, 1970, pp. 1-15.

[17] S. K. Biswas, "A Review on the Evolution of Rift Basins in India during Gondwana with Special Reference to Western Indian Basins and Their Hydrocarbon Prospects,"
Proceedings of Indian National Science Academy Special Issue, Vol. 65, No. 3, 1999, pp. 261-283.

[18] S. K. Acharyya and A. Roy, "Tectono-Thermal History of the Central Indian Tectonic Zone and Reactivation of Major Fault/Shear Zones,” Journal of Geological Society of India, Vol. 55, No. 3, 2000, pp. 239-256.

[19] R. C. Tewari, "Sedimentary-Tectonic Status of PermianTriassic Boundary (250Ma) in Gondwana Stratigraphy of Peninsular India," Gondwana Research, Vol. 2, No. 2, 1999, pp. 185-189.

http://dx.doi.org/10.1016/S1342-937X(05)70142-8

[20] S. M. Casshyap and H. A. Qidwai, "Glacial Sedimentation of Late Palaeozoic Talchir diamictite, Pench Valley Coalfields, Central India,” Geological Society of America Bulletin, Vol. 85, No. 5, 1974, pp.749-760. http://dx.doi.org/10.1130/0016-7606(1974)85<749:GSOL PT>2.0.CO;2

[21] S. N. Das and D. P. Sen, "Depositional History of PermoCarboniferous Tillites and Associated Sediments in West Bokaro Gondwana Basin, Bihar,” Journal of the Geological Society of India, Vol. 21, No. 1, 1980, pp. 30-38.

[22] R. C. Tewari and S. M. Casshayap, "Palaeoflow Analysis of Late Paleozoic Gondwana Deposits of Giridih and Adjoining Basins and Paleogeographic Implications," Geological Society of India, Vol. 23, No. 2, 1982, pp 6779.

[23] N. Eyles and A. M. McCabe, "The Late Devensian (<22000YBP) Irish Sea Basin: The Sedimentary Record of a Collapsed Ice Sheet Margin,” Quaternary Science Review, Vol. 8, No. 4, 1989, pp. 307-351. http://dx.doi.org/10.1016/0277-3791(89)90034-6

[24] P. K. Bose, G. Mukhopadhyay and H. N. Bhattacharya, "Glaciogenic Coarse Clastics in a Permo-Carboniferous Bedrock trough in India: A Sedimentary Model," Sedimentary Geology, Vol. 76, No. 1-2, 1992, pp. 79-97. http://dx.doi.org/10.1016/0037-0738(92)90140-M

[25] G. Mukhopadhyay and H. N. Bhattacharya, "Facies Analysis of Talchir Sediments (Permo-Carboniferous), Dudhi Nala, Bihar, India-A Glaciomarine Model,” IXth International Gondwana Symposium, Oxford and IBH Publication, New Delhi, Vol. 2, 1994, pp. 737-753.

[26] J. J. Veevers and R.C. Tewari, “Gondwana Master Basin of Peninsular India between Tethys and the Interior of the Gondwanaland Province of Pangea," Memoire of the Geological Society of America, No. 187, 1995, pp. 1-73.

[27] W. Maejima, R. Das, K. L. Pandya and M. Hayashi, "Deglacial Control on Sedimentation and Basin Evolution of Permo-Carboniferous Talchir Formation, Talchir Gondwana Basin, Orissa, India,” Gondwana Research, Vol. 72, No. 2, 2004, pp. 339-352. http://dx.doi.org/10.1016/S1342-937X(05)70788-7

[28] H. N. Bhattacharya, B. Bhattacharya, I. Chakraborty and A. Chakraborty, "Sole Marks in Storm Event Beds in the Permo-Carboniferous Talchir Formation, Raniganj Basin, India,” Sedimentary Geology, Vol. 166, No. 3-4, 2004, pp. 209-222. http://dx.doi.org/10.1016/j.sedgeo.2003.12.003

[29] H. N. Bhattacharya, A. Chakraborty and B. Bhattacharya, "Significance of Transition between Talchir Formation 
and Karharbari Formation in Lower Gondwana Basin Evolution-A Study in West Bokaro Coal Basin, Jharkhand, India,” Journal of Earth System Science, Vol. 114, No. 3, 2005, pp. 275-286. http://dx.doi.org/10.1007/BF02702950

[30] H. N. Bhattacharya and B. Bhattacharya, “A PermoCarboniferous Tide-Storm Interactive System: Talchir Formation, Raniganj Basin, India," Journal of Asian Earth Sciences, Vol. 27, No. 3, 2006, pp. 303-311. http://dx.doi.org/10.1016/j.jseaes.2005.04.006

[31] H. N. Bhattacharya and B. Bhattacharya, "Soft Sediment Deformation Structures from an Ice-Marginal Storm-Tide Interactive System, Permo-Carboniferous Talchir Formation, Talchir Coalbasin, India,” Sedimentary Geology, Vol. 223, No. 3-4, 2010, pp. 380-389. http://dx.doi.org/10.1016/j.sedgeo.2009.12.002

[32] B. Bhattacharya and H. N. Bhattacharya, "Implications of Mud-Clast Conglomerates within Late Palaeozoic Talchir Glacio-Marine Succession, Talchir Basin, India,” Indian Journal of Geosciences, Vol. 66, No. 1, 2012, pp. 69-78.

[33] C. S. Rao Raja, “Chirimiri Coalfield,” In: Coal Resources of Madhya Pradesh and Jammu \& Kashmir, Bulletins of Geological Survey of India, Series A, Vol. 3, No. 45, 1983, pp. 44-55.

[34] A. Roy, H. M. Ramchandra and B. K. Bandyopadhyay, "Supracrustal Belts and Their Significance in the Crustal
Evolution of Central India," Proceedings Dr. M.S Krishnan Birth Cent, Sem., Geological Survey of India, Special Publication, No. 55, 2000, pp. 361-380.

[35] S. Dotiwala and K. K. S. Pangtey, KDMIPE, AAPG, Search and Discovery Article, American Association of Petroleum Geologist, International Conference and Exhibition, Vienna, 1997.

[36] R. V. Ingersoll, T. F. Bullard, R. L. Ford, J. P. Grimm, J. D. Pickle and S. W. Sares, "The Effect of Grain Size on Detrital Modes: A Test of the Gazzi-Dickinson Point Counting Method,” Journal of Sedimentary Research, Vol. 54, No. 1, 1984, pp. 103-106.

[37] R. L. Folk, “Petrology of Sedimentary Rocks,” Hemphill, Austin, 1980.

[38] F. J. Pettijohn, “Sedimentary Rocks,” 3rd Edition, Harper and Row, New York, 1975, 628pp.

[39] R. G. Walker, "Colour of Recent Sediments in Tropical Mexico: A Contribution to the Origin of Red Beds," Geological Society of America Bulletin, Vol. 78, No. 7, 1967, pp. 917-920.

http://dx.doi.org/10.1130/0016-7606(1967)78[917:CORS IT]2.0.CO;2

[40] R. L. Folk, "Bimodal Supermature Sandstones: Product of Desert Floor," Proceedings 23rd International Gondwana Congress, Vol. 8, 1968, pp. 9-32. 